[программно-метод. пособ.] / В. П. Сергеева, С. В. Грицаева. - М., 1999. - 93 с. 13. Системное познание мира: методологические проблемы / А. Н. Аверьянов. - М. : Политиздат, 1985. - 263 с. 14. Словарь-справочник педагогических инноваций в образовательном процессе / [сост. Л. В. Трубайчук] . - М. : Восток, 2001. - 81 с. 15. Тюхтин В. С. Диалектика познания сложных систем / В. С. Тюхтин [и др.]; под ред. В. С. Тюхтина. - М. : Мысль, 1988.- 316 с. 16. Юдин Э. Г. Системный подход и принцип деятельности: методологические проблемы современной науки / Э. Г. Юдин. - М. : Наука, 1978. - 391 с.

Наталія Чувасова

\title{
КРЕАТИВНІСТЬ ОСОБИСТОСТІ: ЗМІСТ І СТРУКТУРА
}

Чувасова Н. О. Креативність особистості: зміст і структура.

У статті розглядаються різні підходи до визначення змісту і структури креативності та творчості особистості. На основі здійсненого аналізу автор виокремлює критерії та показники формування креативності майбутніх педагогів природничих дисциплін в умовах університету.

Ключові слова: креативність, креативне мислення, креативне навчання, творчість, обдарованість, творчі здібності, творча особистість.

Чувасова Н. А. Креативность личности: содержание и структура.

В статье рассматриваються различные подходы к определению содержания и структуры креативности и творчества личности. На основе проведенного анализа автор выделяет критерии и показатели формирования креативности будущих педагогов естественных дисциплин в условиях университета.

Ключевые слова: креативность, креативное мышление, креативное обучение, творчество, одаренность, творческие способности, творческая личность.

Chuvasova N. A. Personality creativity: the content and structure.

Some different approaches to the determination of the content and the structure of the Natural Sciences teacher-to-be's creativity have been considered in the article. Taking as a base the analysis carried out, the author has determined the criteria and the indicators of the Natural Sciences teacherto-be's creativity while studying at University.

Keywords: creativity, creative thinking, creative teaching, creation, endowment, creative abilities, creative person.

Нині в Україні, як і в усьому світі, створюються передумови для перегляду теоретичних основ і технологій підготовки майбутніх педагогів природничих дисциплін до професійної діяльності. Подолання репродуктивного стилю підготовки майбутніх фахівців і перехід до нової освітньої парадигми передбачає і нові вимоги до підготовки майбутніх педагогів природничих дисциплін, які забезпечують пізнавальну активність, креативність дій i самостійність мислення особистості і $€$ стратегічними напрямами в модернізації вищої педагогічної освіти. На сучасному етапі перед вищими навчальними закладами постає завдання переорієнтувати навчальний процес на формування креативної особистості, здатної самостійно здобувати знання з різних джерел інформації та застосовувати їх у практичному житті.

Проблема креативності досліджувалася багатьма зарубіжними та вітчизняними науковцями, зокрема, такими, як: Д. Богоявленська, Н. Вишнякова, Дж. Гілфорд, В. Клименко, А. Лук, С. Мєднік, Л. Міщиха, В. Моляко, М. Ніколаєнко, Я. Пономарьов, В. Роменець, С. Рубінштейн, К. Тейлор, Е.Торренс, М.Уоллах, Д. Халперн, М. Ярошевський та ін.

3-поміж праць із психології творчості можна знайти розроблення різноманітних їі аспектів. Це, зокрема, спроби пояснити сутність творчості та творчого процесу (В. Моляко, М. Ніколаєнко, Я. Пономарьов, В. Роменець та ін.), визначити специфіку творчості в тій чи тій галузі знань (Т. Кудрявцев, М. Ярошевський та ін.), пошук шляхів оптимізації та активізації творчого мислення (Г. Альтшуллер, Г. Буш, В. Моляко, І. Семенов та ін).

Важливу роль у розробленні основ теорії творчої особистості відіграли дослідження закономірностей творчого процесу в різноманітних видах діяльності, які знайшли своє 
відображення у фундаментальних працях Л. Виготського, О. Леонтьева, Г. Костюка, С. Рубінштейна, Б. Теплова, О. Ковальова, Т. Кудрявцева, Ю. Кулюткіна, С. Максименка, О. Матюшкіна, Я. Пономарьова, Г. Сухобської та ін. Їх доповнили дослідження $з$ психології педагогічної діяльності (Н. Кузьміна, В. Сластьонін, А. Щербаков та ін.).

Meта статmi - проаналізувати підходи науковців щодо процесу формування креативності. На нашу думку, розв'язання цієї проблеми вимагає ефективного вивчення психологічних та педагогічних основ креативності та творчості.

До проблеми креативності неодноразово звертались дослідники та, незважаючи на це, вона залишається найменш дослідженою в контексті змісту людської активності. Аналіз наукової літератури дозволяє говорити про різні підходи до розв'язання означеної проблеми та намагання знайти раціональні шляхи підвищення якості педагогічної підготовки майбутніх педагогів у системі університетської освіти, ії особистісної спрямованості під час вивчення природничих дисциплін.

Креативність трактується науковцями з різних позицій як:

- здатність особистості (Е. Торренс, Дж. Гілфорд, Д. Чернілевський, Д. Богоявленська, В. Дружинін та ін);

- риса особистості (К. Тейлор, А. Маслоу, К. Роджерс);

- вияв обдарованості (А. Матюшкін, Дж. Рензуллі, В. Шадриков);

- творча діяльність (А. Хуторський) та ін.

Згідно з позицією В. Дружиніна [4, с. 48], розроблено принаймні три підходи до проблеми творчих здібностей ( креативності):

1. Як таких творчих здібностей не існує. Інтелектуальна обдарованість є необхідною, але недостатньою умовою творчої активності особистості. Головну роль у детермінації творчої поведінки відіграють мотивації, цінності, особистісні риси (Д. Богоявленська, А. Маслоу, А. Олох, А. Танненбаум та ін.).

2. Творча здатність (креативність) є самостійним чинником, не залежним від інтелекту (Дж. Гілфорд, Г. Грубер, Я. Пономарьов, К. Тейлор, Е. Торренс та ін.). Головним змістовим компонентом поняття креативності в цьому випадку $є$ дивергентне мислення. Ця теорія стверджує, що між рівнем інтелекту й рівнем креативності є незначна кореляція. Найбільш розвиненою концепцією $є$ «теорія інтелектуального порогу» Е. Торренса.

3. Високий рівень розвитку інтелекту передбачає високий рівень творчих здібностей і навпаки. Творчого процесу як специфічної форми активності не існує. Креативність розуміють як інтелектуальну обдарованість. Цю точку зору підтримували й підтримують практично всі дослідники інтелекту (Г. Айзенк, Р. Вайсберг, Д. Векслер, Р. Стернберг, Л. Термен та ін.).

Концепція креативності як універсальної пізнавальної творчої здатності набула популярності після виходу друком робіт Дж. Гілфорда. Основою цієї концепції стала його кубоподібна модель структури інтелекту. Дж. Гілфорд визначив принципову відмінність між двома типами розумових операцій - конвергентною й дивергентною. Конвергентне мислення (сходження) актуалізується лише в тому випадку, коли людині, яка розв'язує задачу, потрібно знайти єдине правильне рішення. Отже, Дж. Гілфорд ототожнив здатність до конвергентного мислення з тестовим інтелектом, вимірюваним високошвидкісними тестами IQ. Дивергентне мислення визначається як «тип мислення, що розходиться в різних напрямах» [3, с. 4]. Такий тип мислення передбачає варіювання шляхів розв'язання проблеми, призводить до несподіваних висновків і результатів. Дж. Гілфорд уважав операцію дивергенції підгрунтям креативності як загальної творчої здатності. У зв'язку з цим він виокремив чотири критерії дивергентного мислення:

1) оригінальність - здатність продукувати окремі асоціації, незвичайні відповіді;

2) семантичну гнучкість - здатність виявляти головну властивість об'єкта та пропонувати новий спосіб його використання;

3) образну адаптивну гнучкість - здатність змінювати форму стимулу так, щоб побачити в ньому нові ознаки й можливості для використання;

4) семантичну спонтанну гнучкість - здатність продукувати різноманітні ідеї в нерегламентованій ситуації.

Крім того, він визначив шість параметрів креативності:

1) здатність до виявлення й формулювання проблем; 
2) здатність до генерування великої кількості ідей;

3) гнучкість - здатність до продукування різноманітних ідей;

4) оригінальність - здатність відповідати на подразники нестандартно;

5) здатність удосконалювати об'єкт, додаючи деталі;

6) здатність до аналізу й синтезу.

Дивергентне мислення стало визначенням креативності мислення в межах цього напряму. У деяких своїх статтях Дж. Гілфорд розглядав співвідношення інтелекту й креативності. Він уважав, що інтелект визначає успішність розуміння та усвідомлення нового матеріалу, а дивергентне мислення детермінує творчі досягнення. Крім того, успішність творчої активності визначена обсягом знань (що залежать, у свою чергу, від інтелекту). Вплив знань може бути як позитивним, так і негативним: людина має уявляти, що саме вона збирається робити. Занадто усталені знання можуть обмежувати світогляд дослідника, позбавляти його можливості поновому подивитися на проблему. Креативність передбачає здатність іти на розумний ризик, готовність долати перешкоди, внутрішню мотивацію, толерантність до невизначеності, готовність протистояти думці оточення. Для творчості необхідна незалежність мислення від стереотипів і зовнішнього впливу. Творча людина здатна самостійно висувати проблеми й автономно розв'язувати їх. Гілфорд висловлював припущення, що IQ визначатиме «верхню межу» успішності розв'язання задач на дивергентне мислення.

Напрям досліджень, розпочатих Дж. Гілфордом, найбільш послідовно був продовжений Е. Торренсом. В основу циклу його робіт, було покладено припущення про те, що процеси, пов'язані з розв'язанням проблемної ситуації - від виявлення проблеми до повідомлення про іiі розв'язання, - безпосередньо стосуються креативності. Саме це визначення свідчить про те, що Е. Торренс віднотить до виявів креативності не лише специфічні для неї феномени (наприклад, формулювання гіпотез), але й ті особливості, які безпосередньо пов'язані із загальним інтелектом (наприклад, перевірку гіпотез).

Значні перетинання інтелекту й креативності виявлялися й під час експериментального дослідження характеристик креативності, виокремлених Е.Торренсом: швидкості, гнучкості, оригінальності й розробленості.

М. Берштейн уважає, що «творчість вищого порядку $є$ долею одиниць, котрих ми називаємо геніями. Творчість нижчого порядку є справою багатьох, можна навіть сказати майже всіх науковців» [2, с. 161].

Е. Торренс визначає творче мислення як «процес відчуття труднощів, проблем, розривів у інформації, браку елементів, висування гіпотез щодо цих відсутніх елементів, перевірка й оцінювання цих гіпотез; їхній перегляд і повторний огляд; повідомлення результату» [7, с. 5 ].

Дж. Гілфорд, М. Кашапов, Р. Стернберг, Є. Торренс виокремлюють різні параметри креативності, загальними з яких $є$ швидкість, гнучкість, оригінальність мислення і ретельність розроблення рішень (ідей).

Креативна людина володіє більшою привабливістю у спілкуванні. Вона притягує до себе людей. У іï товаристві час спливає непомітно та виникає бажання якомога довше залишатися поруч з нею. При цьому привабливість творчої людини пов'язується не лише з ії постійним розвитком, змінами, але й з ії відкритістю іншому досвіту. А ця відкритість, у свою чергу, завершує це коло чи, точніше, продовжує спіраль розвитку.

Творча людина бачить інших у всій сукупності їхніх рис і властивостей, а за такого погляду люди ні кращі, ні гірші в порівнянні один до одного: вони просто різні. Людина, яка виходить на рівень розвинутої креативності, більш демократична у стосунках з оточуючими. При цьому вона не приймає ніякого насилля чи придушення.

Л. Виготський, І. Волков, І. Лернер, С. Рубінштейн розглядають креативність як творчі можливості, що здатні виражатися в різних видах діяльності особистості, характеризують не тільки особистість, а й ії діяльність. Можна розглядати креативність як здатність до створення нового; як творчий потенціал особистості, здатний реалізуватись у творчому процесі та сформувати на цій основі гармонійну, всебічно розвинену особистість.

В. Рогозіна розглядає креативність як особистісну характеристику, але не як певний набір особистісних рис, а як реалізацію людиною власної індивідуальності. Кожна людина неповторна, унікальна, вона вносить у світ щось нове, таке, чого раніше не було. Тому вияв індивідуальності є творчим процесом. На думку В. Рогозіної, характеристики креативності 
непредметні, тобто не передбачають наявність продукту (матеріального чи ідеального), процесуальні, оскільки креативність розглядається як процес вияву власної індивідуальності. В. Рогозіна виокремлюе такі процесуальні характеристики креативності: а) креативність розкривається в процесі суб'єкт-суб'єктної взаємодії; б) креативність у певній формі завжди адресується іншій людині [5, с. 105$]$.

За визначенням Е. Фромма, креативність - це здатність дивуватися, шукати рішення в нестандартній ситуації, спрямованість на нове і вміння глибоко усвідомлювати власний досвід. «Усередині» феномену креативності визначають його потенційні й актуальні «іпостасі», а також принципово їх розділяють. Це пов'язано з процесами освоєння носієм потенційної креативності того чи того (нового для нього) соціально значимого виду діяльності [6, с. 125].

Якщо Дж. Гілфорд і Е. Торренс розглядають креативність як здатність до творчого (дивергентного) мислення, то Ф. Баррон уважає центральним процес уяви і символізації, визначаючи креативність «як внутрішній процес, який спонтанно продовжується в дії». Р. Стернберг підкреслює важливість здібності створювати «продуктивні метафори» [6, с. 126].

У дослідженнях Дж. Гілфорда та Е. Торренса виявлено високу позитивну кореляцію рівня IQ i рівня креативності. Чим вищий рівень інтелекту, тим більшою є ймовірність того, що досліджуваний матиме високі показники за тестами креативності, хоча в осіб із високорозвиненим інтелектом можуть траплятися і низькі показники креативності. Е. Торренс запропонував теорію інтелектуального порогу: за IQ нижче від 115-120 балів інтелект і креативність утворюють єдиний чинник; за IQ понад 120 - творчі здібності та інтелект стають незалежними чинниками.

Дослідники Г. Айзенк, Д. Векслер, Р. Стенберг, Л. Терме розглядають інтелект і креативність як єдину людську здатність вищого плану.

В. Дружинін охарактеризував цю точку зору «як редукція креативності до інтелекту» $[4$, c. 85]. Ідеться не просто про те, що це єдина здатність, а про те, що творчість похідне інтелекту. Високий інтелект - високі творчі здібності. Низький інтелект - низький хист до творчості. Немає жодної необхідності, уважає Ганс Айзенк, виокремити креативність як особливу здатність. Здатність до будь-якого виду творчості (наукова, художня) забезпечується, передусім, високими значеннями загального інтелекту.

Аналогічно поняттю «творчість» креативність розглядали К. Тейлор, М. Ферсон. К. Тейлор розглядає творчість як розв'язання завдань і виокремлює шість груп визначень творчості:

1. Визначення типу «гештальт», у яких відзначається створення нової цілісності.

2. Визначення, орієнтовані на «кінцевий продукт», або «інноваційні» визначення, у яких виокремлюється продукування чогось нового.

3. «Естетичні», або «експресивні», визначення, у яких відзначається самовираження. Як приклад визначень цього типу наводиться таке: «Творчий процес - це здатність мислити в недослідженій галузі без обмеження набутим досвідом».

4. «Психоаналітичні», або «динамічні», визначення, у яких творчість трактується в термінах взаємодії «Я», «Воно» $\mathrm{i}$ «Над-Я».

5. Визначення в термінах «мислення, орієнтованого на рішення», у яких актуалізується не стільки рішення, скільки власне розумовий процес.

6. Різноманітні визначення, що не вкладаються в жодну з перерахованих вище категорій [6, c. 126].

Креативність як психологічний феномен може характеризуватися такими поняттями, як дивергентність, творче мислення, продуктивне мислення, творча інтуїція. Як властивість особистості є складником структури інтелекту, творчості, різних видів обдарованості та сфери несвідомого. Простір креативних виявів охоплює всі основні сфери, які підлягають психологічному аналізу.

Креативність як специфічна діяльність має певну структуру, компоненти якої перебувають у тісному взаємозв'язку та взаємодоповнюються. До компонентів креативності відносять:

- «свіжість погляду», або вміння побачити нове, яку пов'язують із сенситивністю чутливістю до субдомінантних (неосновних, побічних) утворень, чутливістю до проблем, толерантністю до незрозумілого, допитливістю, латеральним мисленням;

- гнучкість як бачення альтернатив, різних варіантів, різних аспектів проблеми; як здатність змінювати сприймання об'єкта таким чином, щоб бачити нові, приховані від 
спостереження сторони; як вміння знаходити для одного і того ж поняття, символу, образу, предмета все нові й нові семантичні значення;

- оригінальність мислення, яке визначається прагненням до самостійності, незвичності, дотепності розв'язку поставленої задачі. Оригінальність - це найбільш загальна характеристика для оцінки продукту інтелектуальної творчості. 3 практичної точки зору ідея вважається оригінальною, якщо подібної їй немає серед уже відомих;

- мотиваційні механізми креативності, які грунтуються на внутрішніх (на відміну від зовнішньої стимуляції) мотивах творчої активності, серед яких: потреба в новизні, потреба в автономії, свобода вибору, контроль за довкіллям і комунікація з ним, мотив самоактуалізації;

- емоційну забарвленість творчої діяльності, що супроводжується натхненням, упевненістю у виконуваній справі, сумнівами. Креативи вирізняються багатством емоційної сфери, поєднанням у реакціях різноманітних емоцій, багатством переживань;

- несвідомі механізми креативності, які займають визначальне становище під час створення ідеї, тобто на етапі «первинної» креативності. Їх пов'язують 3 актами миттєвого «осяяння», «прозріння», такими, як інтуїція, явище інкубації, інсайту, завдяки чому у творчому процесі забезпечується миттєвість виникнення та цілісність ідеї, раптовість та несподіваність отриманого результату, парадоксальність, поєднання різнорідних фактів, невідповідність стандартам і правилам, нестереотипність, здатність передбачати, що задана низка явищ та ідей має важливе значення.

Креативне мислення передбачає розумову концентрацію на проблемі, зосередження на ній інтелектуальних зусиль, а також наявність у суб'єкта діяльності певних знань, досвіду й бажання пізнати суть явищ.

У своєму дослідженні з формування креативності майбутніх педагогів природничих дисциплін в умовах університету ми спираємося на думку дослідника креативності Д. Реута [5, c. 96]. Він виокремлює первинну та вторинну креативність. Автор розуміє креативний акт як суб'єктивний. Тобто новим є те, що вперше мислить або робить суб'єкт, те, що раніше було йому незнайомим. Тобто креативний акт кваліфікується як такий за критерієм новизни для самого суб'єкта. Тоді максимально креативною є дитина: вона все робить уперше. Це і $є$ первинна креативність. Проте пізнання світу $є$ неперервним, і це постійно звужує поле креативності зростаючої людини. Одночасно зростають можливості для вторинної, «комбінаторної» креативності. Під вторинною креативністю Д. Реут розуміє породження відносної новизни: культурне перенесення ідей, понять структур з однієї галузі в іншу. Продукт первинної або вторинної креативності використовується тією особистістю, що їх спродукувала, а також піддається експертизі відповідних інститутів і або відкидається, або приймається до використання в масштабах більш-менш широкої людської спільноти.

Проаналізувавши різні підходи як вітчизняних, так і зарубіжних дослідників, ми виокремили два найбільш поширених уявлення про феномен креативності:

1. Визначення креативності, виходячи $з$ творчого досягнення; згідно з цим визначенням, креативність - це діяльність людини, що створює нові оригінальні цінності.

2. Креативність як початкова здатність людини до діяльності в самовираженні i самоактуалізації. У сучасних дослідженнях має місце тенденція розгляду креативності як комплексу інтелектуальних особливостей індивіда, притаманних кожній особистості.

На нашу думку, процес навчання майбутніх педагогів природничих дисциплін буде ефективним, якщо студент розуміє, точніше, робить для себе більш зрозумілим власний процес навчання. Задля цього ми вводимо такі принципи креативного навчання, як сукупність трьох складників:

- усвідомленості (досягається в ході рефлексії процесу і результату);

- управління власною увагою;

- зміни (задля покращення) з подальшим розвитком в процесі постійного руху від одного стану до іншого: від менш ефективного до більш результативного.

Для формування креативності майбутніх педагогів природничих дисциплін в умовах університету потрібно створити й оптимальні умови. Для цього слід:

1) сприймати найдивовижніші ідеї,

2) уникати негативного оцінювання ідей студентів;

3) уважно ставитись до будь-яких запитань кожного студента; 
4) підтримувати віру у власні сили і висловлювати співчуття при невдачах;

5) створювати ситуації успіху, інколи покладатися на ризик та інтуїцію: найімовірніше, що саме це допоможе зробити справжнє відкриття.

Креативність як мета професійної підготовки майбутніх педагогів прогнозує формування творчої особистості в усіх видах діяльності, діалогічну взаємодію та спілкування, перебудову креативного стилю діяльності студентів з оволодіння знаннями природничих дисциплін.

Отже, у наукових дослідженнях креативності все більше поширюється думка про те, що здатність до креативності не виняткове явище, притаманне видатним діячам науки, техніки й культури, а, навпаки, таке, що певною мірою характеризує всіх людей. Окрім того, цю здатність можна виявляти, стимулювати та розвивати цілеспрямовано, підвищуючи ефективність продуктивної діяльності майбутніх педагогів природничих дисциплін i використовувати креативний потенціал на користь самої людини та суспільства.

\section{Література}

1. Айзенк Г. Ю. Интеллект: новый вигляд / Г. Ю. Айзенк // Вопросы психологии. - 1995.- № 1. С. 111-131. 2. Берштейн М. С. Психология научного творчества / М. С. Берштейн // Вопросы психологии. -1965. - № 3. - С. 156-164. 3. Гилфорд Дж. Структурная модель интеллекта / Джо Пол Гилфорд. - М. : Прогрес, 1965. - 14 с. 4. Дружинин В. Н. Психология общих способностей (интелект, обучаемость, креативность) / Владимир Николаевич Дружинин. - СПб. : Питер, 1999. - 368 с. 5. Реут Д. Сладкое проклятие креативности. Когнитивный анализ и управление развитием ситуаций (CASC'2001). Труды 1-й международной конференции (г. Москва, 11-12 октября 2001 г.). - Т. 3.- М. : Институт проблем управления РАН. - С.91-123 6. Торшина К. А. Современные исследования проблемы креативности в зарубежной психологи / К. А. Торшина // Вопросы психологии. - 1998. № 4. - С. 123-132. 7. Туник Е. Е. Диагностика креативности. Тест Торренса. Методическое руководство / Е. Е. Туник. - СПб. : Иматон, 1998. - 78 с.

\section{ПЕДАГОГІЧНІ ТЕХНОЛОГІЇ ВИХОВАННЯ У СТУДЕНТСЬКОЇ МОЛОДІ КУЛЬТУРИ КОРИСТУВАННЯ КІБЕРПРОСТОРОМ}

Шайкіна О. О. Педагогічні технології виховання у студентської молоді культури користування кіберпростором.

У статті розкрито зміст педагогічних технологій виховання у студентської молоді культури користування кіберпростором: 1) профілактична педагогічна технологія спрямована на запобігання формування у студентської молоді комп'ютерної залежності; 2) педагогічна технологія зниження і подолання комп'ютерної залежності розроблена для студентів, які вже мають таку залежність.

Ключові слова: культура користування кіберпростором, естетотерапія, кіберзалезність, арттерапія, емоційне насичення.

Шайкина Е. А. Педагогические технологии воспитания у студенческой молодежи культуры пользования киберпространством.

В статье раскрыто содержание педагогических технологий воспитания у студенческой молодежи культуры пользования киберпространством: 1) профилактическая педагогическая технология направлена на предотвращение формирования у студенческой молодежи компьютерной зависимости; 2) педагогическая технология снижения и преодоления компьютерной зависимости разработана для студентов, которые уже имеют такую зависимость.

Ключевые слова: культура пользования киберпространством, эстетотерапия, киберзависимость, арт-терапия, эмоциональное насыщение.

Shaykina E. A. Pedagogical technologies of student youth culture of cyberspace usage formation.

The author of the article examines pedagogical technologies of student youth culture of cyberspace usage formation: 1) The preventive pedagogical technology is directed at prevention of computer dependence formation at student youth; 2) Pedagogical technology of decrease and overcoming of computer dependence is developed for students who already have such dependence.

Key words: culture of cyberspace usage, aesthetic therapy, cyberdependence, art therapy, emotional saturation. 